\title{
Evaluation of Some Weibull Parameter Estimation Methods for Characterizing Stem Diameter Distribution in a Tropical Mixed Forest of Southern Nigeria
}

\author{
A.A. Adeyemi \\ Department of Forestry and Wildlife Technology, Federal University of Technology, Owerri, Nigeria \\ P.O. Adesoye \\ Department of Forest Resources Management, University of Ibadan, Nigeria
}

\begin{abstract}
Stem diameter distribution information is useful in forest management planning. Weibull function is flexible, and has been used in characterising diameter distributions, especially in single-species planted stands, the world over. We evaluated some Weibull parameter estimation methods for stem diameter characterisation in (Oban) multi-species Forest in southern Nigeria. Four study sites (Aking, Ekang, Erokut and Ekuri) were selected. Four 2 $\mathrm{km}$-long transects situated at $600 \mathrm{~m}$ apart were laid in each location. Five $50 \mathrm{~m} \times 50 \mathrm{~m}$ plots were alternately laid along each transect at $400 \mathrm{~m}$ apart (20 plots/location) using systematic sampling technique. Tree growth variables: diameter at breast height (Dbh), diameters at the base, middle and merchantable limit, total height, merchantable height, stem straightness, crown length and crown diameter were measured on all trees $\geq 10 \mathrm{~cm}$ to compute model response variables such as mean diameters, basal area and stem volume. Weibull parameters estimation methods used were: moment-based, percentile-based, hybrid and maximum-likelihood (ML). Data were analysed using descriptive statistics, regression models and ANOVA at $\alpha_{0.05}$. Percentile-based method was the best for Weibull [location (a), scale (b) and shape (c)] parameters estimations with $\mathrm{mLogL}=116.66 \pm 21.89$, while hybrid method was least-suitable $(\mathrm{mLogL}=690.14 \pm 128.81)$ for Weibull parameters estimations. Quadratic mean diameter $\left(\mathrm{D}_{\mathrm{q}}\right)$ was the only suitable predictor of Weibull parameters in Oban Forest.
\end{abstract}

Keywords: Diameter distribution, parameter estimation methods, prediction models

\section{Introduction}

Diameter distribution is used in most forest management planning packages for predicting stand volume and stand growth (e.g. Sharma and Parton, 2007; Osman et al., 2013). The information on diameter distribution can then serve as input for stem biomass and carbon stock estimation by establishing allometric relationships between stem biomass and diameter or stem volume (Beets et al., 2012; Özçelik et al., 2014). Moreover, forest managers may be interested in estimating the number of trees in different diameter classes in a stand, because the size of the diameter partly determines the industrial use of wood and thus the price of the different products.

Corresponding Author's: adesoji.adeyemi@futo.edu.ng, adeyemiadesoji@yahoo.com, Phone: +2348032082627

Corresponding Author: A.A. Adeyemi, PhD (Forest Biometrics and Remote Sensing), Department of Forestry and Wildlife Technology, Federal University of Technology, Owerri, Nigeria 
Diameter distributions also provide information about stand stability, and enable planning of silvicultural treatments (Gorgoso-Varela et al., 2012; Caetano et al., 2014).

Diameter distributions can be used to indicate whether the density of smaller trees in a stand is sufficient to replace the current population of larger trees and to help evaluate potential forest sustainability (Sheykholeslami et al., 2011). Since the age of trees is difficult to determine in natural forests, maturity is usually defined by stem diameters. Furthermore, a successful diameter-distribution model requires good prediction or estimation of its parameters. However, this can only be achieved when the most adequate method(s) are adopted. And such confirmation can only be ascertained through a comparative investigation involving all the available estimation methods in a single study and same dataset.

For generally accepted cases considering mixed species stands, Weibull distribution has continuously proven the best of all (McLaughlin, 2014). Similarly, studies abound for Weibull parameter estimation methods in planted stands, and with varied degrees of success (e.g. Adesoye, 2002; Cao, 2007; Podlaski, 2008; Sheykholeslami et al., 2011; Ajayi, 2013; Poudel and Cao, 2013). The applicability and suitability of different estimation methods in tropical rainforests, particularly Oban forest, have not been tested. And the most appropriate method(s) for parameter estimations in a tropical rainforest is yet to be ascertained. Therefore, we evaluated four Weibull parameter estimation methods on the same dataset with a view to ascertaining the most appropriate.

\section{Method}

\section{The Study Area}

This study was carried out in the Oban Forest, which occupies an area of about 251,345 ha in the southern part of Nigeria, within longitudes $8^{\circ} 02^{\prime}$ and $8^{\circ} 55^{\prime} \mathrm{E}$ and latitudes $5^{\circ} 00^{\prime}$ and $6^{\circ} 00^{\prime} \mathrm{N}$ in Akamkpa and Etung Local Government Areas of Cross River State. The forest is bounded by Korup National Park and Ejagham Forest Reserve of Cameroon in the east (Fig. 1). Annual rainfall is generally high throughout the area and decreases from about 3,000 $\mathrm{mm}$ in the south to $2,500 \mathrm{~mm}$ in the north of the Oban forest. This general trend is affected locally by altitude resulting in higher rainfall in hilly and mountainous areas. The central parts of the forest are estimated to receive about 4,000 $\mathrm{mm}$ (Oates et al., 2007). Rain falls in one season from March to November with a peak in June and July, and a second peak in September. There is a marked dry season of three to four months between December and February with very few days of rains; the dry season is longer in the north than in the southern part.

The mean annual temperature in the area is $27^{\circ} \mathrm{C}$. The temperatures vary slightly throughout the year with annual range of monthly average temperature of between $3^{\circ}$ and $3.5^{\circ} \mathrm{C}$. February/March and November are the hottest months with August being the coolest in the area (Oates et al., 2007). Mean monthly relative humidity varies between $78 \%$ and $91 \%$ with an average of $85 \%$. The prevailing wind is southerly, but during the dry season, the north-east trade winds carry dust-laden air from the Sahara (the Harmattan), as far as Calabar (Oates et al., 2007). The Oban Forest is the most extensive area of relatively undisturbed tropical moist forest remaining in Nigeria. It contains approximately $21 \%$ of the remaining $1,187,488$ ha tropical rainforest in Nigeria (Ojonigu et al., 2010), and 52.34\% of the standing tropical rainforest (480, 216 ha) in Cross River State (NFIS, 2011). 
Distribution in a Tropical Mixed Forest of Southern Nigeria

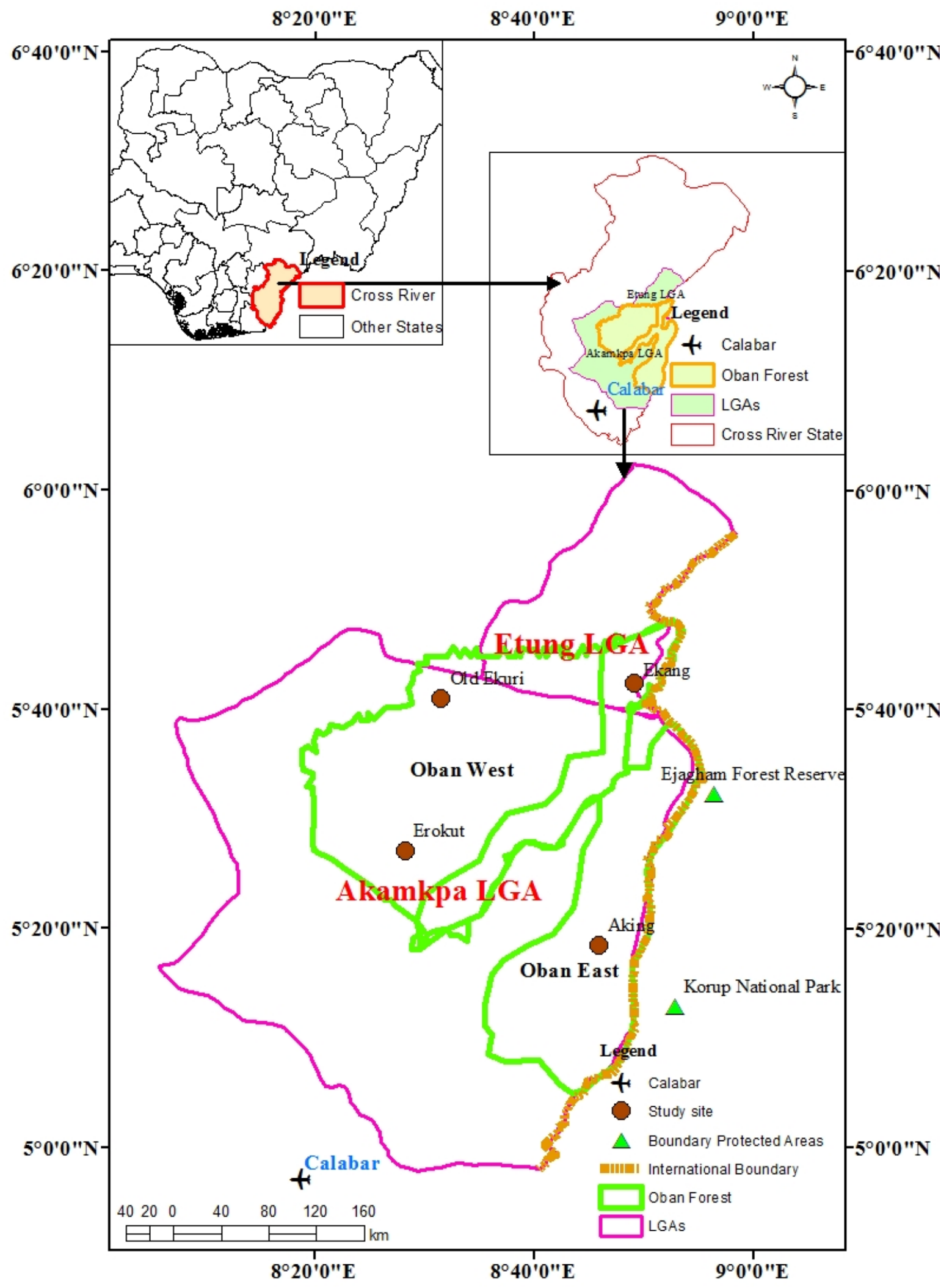

Figure 1. Map of the study area. 


\section{Data Collection}

Data were collected at four study sites (Aking, Ekang, Erokut and Ekuri) within the forest. Systematic (line transect) sampling technique was adopted for plot locations in each of the sites. A distance of $100 \mathrm{~m}$ from the forest boundary was measured to locate the first transect in order to avoid edge effect. The starting point of each transect was determined with the aid of prismatic compass and global positioning systems (GPS) receiver (Husch et al., 2003). Four transects of $2 \mathrm{~km}$ long situated $600 \mathrm{~m}$ apart were cut in each of the locations. Five 0.25 ha (i.e. $50 \mathrm{~m} \times 50 \mathrm{~m}$ ) plots were then alternately laid along each of the transects at $400 \mathrm{~m}$ intervals resulting to 20 plots per location. Hence, eighty (80) sample plots were used for the study. The sampling procedure also ensured that all the possible variations within the forest were captured.

The following measurements were collected on all the trees with $\mathrm{Dbh} \geq \mathrm{cm}$ within each of the sample plots: diameter at breast height $(\mathrm{Dbh})$; diameter, over bark $(\mathrm{cm})$ at the base $\left(\mathrm{D}_{\mathrm{b}}\right)$, middle $\left(\mathrm{D}_{\mathrm{m}}\right)$ and merchantable limit $\left(\mathrm{D}_{\mathrm{t}}\right)$; crown diameter $(\mathrm{CD})$; total height $\left(\mathrm{H}_{\mathrm{t}}\right)$; merchantable height $\left(\mathrm{H}_{\mathrm{m}}\right)$; stem straightness $(\mathrm{SQ})$ and crown length $(\mathrm{CL})$ using Spiegel Relaskop, girth tape and distance measuring tape.

\section{Data Analysis}

\section{Computation of Model Variables}

Arithmetic mean diameter was computed as:

$$
\bar{D}=\frac{1}{n} \sum_{i=1}^{n} D_{i}
$$

Where,

$D_{i}=$ Dbh of $i t h$ tree $(\mathrm{cm}) ; n=$ total number of trees per plot.

Quadratic mean diameter was computed using:

$$
\bar{D}_{q}=\sqrt{\frac{1}{n} \sum_{i=1}^{n} D_{i}^{2}}
$$

Where, $D_{i}$ and $n$ are as defined in eqn. 1 .

\section{Development of Diameter Distribution Models}

The Weibull probability density function (pdf) that was used in this study is a three-parameter Weibull distribution function, and is given as:

$$
f(x ; a, b, c)=\left(\frac{c}{b}\right)\left(\frac{x-a}{b}\right)^{c-1} \exp \left[-\left(\frac{x-a}{b}\right)^{c}\right] ; x \geq a
$$

Where,

$x=$ tree diameter at breast height (Dbh); $a=$ location parameter (minimum Dbh in the stand) and $b=$ scale parameter, $c=$ shape parameter.

\section{Weibull Parameter Recovery Methods}

The following major parameter recovery methods were used: moment-based; percentile-based; hybrid and the maximum likelihood methods. In each of the methods, there were sub-versions and/or modifications. 
Evaluation of Some Weibull Parameter Estimation Methods for Characterizing Stem Diameter 261 Distribution in a Tropical Mixed Forest of Southern Nigeria

\section{Moment-based Parameter-recovery Method}

For the two approaches, the location parameter was estimated from the predicted minimum diameter in the stand as follows:

$$
a=0.5 \overline{\bar{D}}_{0}
$$

Under the first approach, the predicted mean diameter and diameter variance were used to recover the scale and shape parameters as follows:

$$
\begin{gathered}
b=\frac{\overline{\bar{D}}-a}{G_{i}} \\
G_{i}=\Gamma(1+i / c) \\
c=b^{2}\left(G_{2}-G_{1}^{2}\right)-D_{\text {var }}
\end{gathered}
$$

Where, $\overline{\bar{D}}=$ the predicted mean diameter and $\Gamma($ () is a complete gamma function.

Under the second approach, the Weibull parameters were recovered from quadratic mean diameter and diameter variance as follows:

$$
\begin{gathered}
b=-G_{1} / G_{2}+\left[\left(a / G_{2}\right)^{2}\left(G_{1}^{2}-G_{2}\right)+\widehat{D}_{q}^{2} / G_{2}\right]^{0.5} \\
c=b^{2}\left(G_{2}-G_{1}^{2}\right)-\widehat{D}_{\mathrm{var}}
\end{gathered}
$$

Where, $D_{q}=$ quadratic mean diameter; $\widehat{D}_{\text {var }}=$ predicted diameter variance.

\section{Percentile-based Parameter-recovery Method}

The method involved the use of different combinations of diameter percentiles in recovering the Weibull scale and shape parameters. Under the first approach, $25^{\text {th }}$ and $95^{\text {th }}$ percentiles were used to recover shape and scale parameters as follows:

$$
\begin{gathered}
c=\frac{\ln \left[\ln \left(1-P_{95}\right) / \ln \left(1-P_{25}\right)\right]}{\ln \left(\hat{D}_{95}-a\right)-\ln \left(\hat{D}_{25}-a\right)} \\
b=\frac{\hat{D}_{95}-a}{\left[-\ln \left(1-P_{95}\right)\right]^{1 / c}}
\end{gathered}
$$

Where, $\hat{D}_{25}$ and $\hat{D}_{95}=$ the predicted diameters at $25^{\text {th }}$ and $95^{\text {th }}$ percentiles; $P_{25}$ and $P_{95}=$ the $25^{\text {th }}$ and $95^{\text {th }}$ percentiles respectively. Under the second approach, $24^{\text {th }}$ and $93^{\text {rd }}$ percentiles were used for shape and scale parameters recovery as follows: 


$$
\begin{gathered}
c=\frac{\ln \left[\ln \left(1-P_{93}\right) / \ln \left(1-P_{24}\right)\right]}{\ln \left(\widehat{D}_{93}-a\right)-\ln \left(\hat{D}_{24}-a\right)} \\
b=\frac{\widehat{D}_{93}-a}{\left[-\ln \left(1-P_{93}\right)\right]^{1 / c}}
\end{gathered}
$$

Where, $\hat{D}_{24}$ and $\hat{D}_{93}=$ predicted diameters at $24^{\text {th }}$ and $93^{\text {rd }}$ percentiles; $P_{24}$ and $P_{93}=24^{\text {th }}$ and $93^{\text {rd }}$ percentiles respectively.

Under the third approach, $31^{\text {st }}$ and $63^{\text {rd }}$ percentiles were used to recover shape and scale parameters as follows:

$$
\begin{gathered}
c=\frac{\ln \left[\ln \left(1-P_{63}\right) / \ln \left(1-P_{31}\right)\right]}{\ln \left(\hat{D}_{63}-a\right)-\ln \left(\hat{D}_{31}-a\right)} \\
b=\frac{\hat{D}_{63}-a}{\left[-\ln \left(1-P_{63}\right)\right]^{1 / c}}
\end{gathered}
$$

Where, $\hat{D}_{31}$ and $\hat{D}_{63}=$ predicted diameters at $31^{\text {st }}$ and $63^{\text {rd }}$ percentiles; $P_{31}$ and $P_{63}=31^{\text {st }}$ and $63^{\text {rd }}$ percentiles respectively.

Under the fourth approach, $24^{\text {th }}$ and $63^{\text {rd }}$ percentiles were used for shape and scale parameters recovery as follows:

$$
\begin{gathered}
c=\frac{\ln \left[\ln \left(1-P_{63}\right) / \ln \left(1-P_{24}\right)\right]}{\ln \left(\hat{D}_{63}-a\right)-\ln \left(\hat{D}_{24}-a\right)} \\
b=\frac{\hat{D}_{63}-a}{\left[-\ln \left(1-P_{63}\right)\right]^{1 / c}}
\end{gathered}
$$

Where, $\hat{D}_{24}$ and $\hat{D}_{63}=$ the predicted diameters at $24^{\text {th }}$ and $63^{\text {rd }}$ percentiles; $P_{24}$ and $P_{63}$ are $24^{\text {th }}$ and $63^{\text {rd }}$ percentiles respectively.

Under the fifth approach, $25^{\text {th }}$ and $50^{\text {th }}$ percentiles were used for shape and scale parameters recovery as follows:

$$
c=\frac{\ln \left[\ln \left(1-P_{50}\right) / \ln \left(1-P_{25}\right)\right]}{\ln \left(\widehat{D}_{50}-a\right)-\ln \left(\widehat{D}_{25}-a\right)}
$$


Distribution in a Tropical Mixed Forest of Southern Nigeria

$$
b=\frac{\hat{D}_{50}-a}{\left[-\ln \left(1-P_{50}\right)\right]^{1 / c}}
$$

Where, $\hat{D}_{25}$ and $\hat{D}_{50}=$ the predicted diameters at $25^{\text {th }}$ and $50^{\text {th }}$ percentiles; $P_{25}$ and $P_{50}$ are $25^{\text {th }}$ and $50^{\text {th }}$ percentiles respectively.

Under the sixth approach, $50^{\text {th }}$ and $95^{\text {th }}$ percentiles were used to recover shape and scale parameters as follows:

$$
\begin{gathered}
c=\frac{\ln \left[\ln \left(1-P_{95}\right) / \ln \left(1-P_{50}\right)\right]}{\ln \left(\widehat{D}_{95}-a\right)-\ln \left(\widehat{D}_{50}-a\right)} \\
b=\frac{\widehat{D}_{95}-a}{\left[-\ln \left(1-P_{50}\right)\right]^{1 / c}}
\end{gathered}
$$

Where, $\hat{D}_{50}$ and $\hat{D}_{95}=$ the predicted diameters at $50^{\text {th }}$ and $95^{\text {th }}$ percentiles; $P_{50}$ and $P_{95}=50^{\text {th }}$ and $95^{\text {th }}$ percentiles respectively.

\section{Hybrid Method}

This method involved combinations of the moment-based and percentile-based methods for Weibull parameters recovery. The first approach involved the use of arithmetic mean diameter and the $24^{\text {th }}$ percentile for scale and shape parameters recovery as follows:

$$
\begin{gathered}
b=\frac{\hat{D}_{24}-a}{\left[-\ln \left(1-p_{24}\right)\right]^{1 / c}} \\
c=a+b \Gamma(1+1 / c)-\bar{D}=0
\end{gathered}
$$

The second approach involved the use of arithmetic mean diameter and the $31^{\text {st }}$ percentile for scale and shape parameters recovery.

$$
b=\frac{\widehat{D}_{31}-a}{\left[-\ln \left(1-p_{31}\right)\right]^{1 / c}}
$$

The shape parameter, c, was then obtained from:

$$
a+b \Gamma(1+1 / c)-\bar{D}=0
$$

The third approach involved the use of arithmetic mean diameter and the $63^{\text {rd }}$ percentile for scale and shape parameters recovery.

$$
b=\frac{\widehat{D}_{63}-a}{\left[-\ln \left(1-p_{63}\right)\right]^{1 / c}}
$$




$$
a+b \Gamma(1+1 / c)-\bar{D}=0
$$

The fourth approach involved the use of arithmetic mean and the 95th percentile for scale and shape parameters recovery.

$$
\begin{gathered}
b=\frac{\hat{D}_{95}-a}{\left[-\ln \left(1-p_{95}\right)\right]^{1 / c}} \\
a+b \Gamma(1+1 / c)-\bar{D}=0
\end{gathered}
$$

The fifth approach involved the use of quadratic mean diameter and two percentiles for the shape and scale parameters recovery as follows:

$$
\begin{gathered}
c=-\frac{\ln \left[\ln \left(1-P_{95}\right) / \ln \left(1-P_{25}\right)\right]}{\ln \left(\widehat{D}_{P_{95}}-a\right)-\ln \left(\widehat{D}_{P_{25}}-a\right)} \\
b=-G_{1} / G_{2}+\left[\left(a / G_{2}\right)^{2}\left(G_{1}^{2}-G_{2}\right)+\widehat{D}_{q}^{2} / G_{2}\right]^{0.5}
\end{gathered}
$$

\section{Maximum Likelihood (ML) Method}

The ML estimation method, used by Eerikäinen and Maltamo (2003) and Gorgoso-Varela et al. (2012), enabled the estimation of the Weibull distribution parameters through iterative procedures as follows:

$$
\begin{gathered}
c=\frac{1}{-\frac{1}{n} \sum_{i=1}^{n}\left(x_{i}-a\right)+\frac{\sum_{i=1}^{n}\left(x_{i}-a\right)^{c} \ln \left(x_{i}-a\right)}{\sum_{i=1}^{n}\left(x_{i}-a\right)^{c}}} \\
b=\left[\frac{1}{n} \sum_{i=1}^{n}\left(x_{i}-a\right)^{c}\right]^{\frac{1}{c}}
\end{gathered}
$$

Where, $n=$ the number of sample observations in a Weibull distribution, $x_{i}=$ the individual tree Dbh $(\mathrm{cm})$.

\section{Assessment of Parameter Estimation Methods}

The evaluation statistics adopted in this method was negative $\log$-likelihood $(m L o g L)$ statistics. It produced a more consistent results compared to the other goodness-of-fit statistics tried. The method(s) and/or approaches producing the lowest value(s) of the statistics are the bests. It was computed for each of the methods and/or approaches as using:

$$
m \log L=\sum_{j=1}^{n_{i}}\left[\ln (b)-\ln (c)+(1-c) \ln \left(\frac{x_{i j}-a}{b}\right)+\left(\frac{x_{i j}-a}{b}\right)^{c}\right]
$$

Where, $m \log L=$ negative value of the $\log$-likelihood function of the Weibull distribution;

$n_{i}=$ the number of trees in the $i$ th plot; $x_{i j}=$ the Dbh of tree $j$ in the ith plot; $a, b$ and $c$ are the Weibull location, scale and shape parameters respectively. 
Evaluation of Some Weibull Parameter Estimation Methods for Characterizing Stem Diameter 265 Distribution in a Tropical Mixed Forest of Southern Nigeria

\section{Diameter Distribution Model Fitting}

During the model-fitting process, all the tree growth variables measured (i.e. $\mathrm{H}_{\mathrm{t}} \mathrm{H}_{\mathrm{m}}, \mathrm{SQ}, \mathrm{CD}, \mathrm{Dbh}, \mathrm{D}_{\mathrm{b}}, \mathrm{D}_{\mathrm{m}}$, $D_{t}$, as well as the computed tree variables at individual tree (i.e. arithmetic mean diameter, quadratic mean diameter) and whole-stand (number of trees/ha, basal area/ha, and stem volume/ha) levels were tried as independent variables. The response (dependent) variables were Weibull parameters. The general form of the models is of the form:

$$
f(a, b, c)=b_{o}+b_{1} X_{1}+b_{2} X_{2}+b_{3} X_{3}+b_{n} X_{n}+e_{i}
$$

Where, $a, b, c$ are the predicted Weibull location, scale and shape parameters, $\mathrm{x}_{1}, \ldots \ldots,{ }_{n}$ are the predictors, which represent growth variables at both individual tree and whole-stand levels, $b_{o}, \ldots, b_{n}$ are regression parameters, $e_{i}$ is the standard error term in the regression equations.

\section{Model Evaluation}

Model evaluation is an important aspect of model building. It is imperative that some examination of model be made at all stages of model design, fitting and implementation. Therefore, thorough evaluation of models involved two major steps, which were model verification and model validation.

\section{Model Verification}

This involved examination of the structure and properties of the models. It implicitly means comparing and evaluating candidate models. The models developed in this study were verified using the following statistics:

\section{Coefficient of Determination $\left(\mathbf{R}^{2}\right)$}

This measured the proportion of variation in the dependent variable that has been accounted, or explained by its relationship with the independent variable(s). It was computed as:

$$
R^{2}=1-\left(\frac{R S S}{T S S}\right)
$$

The $R^{2}$ value ranges between 0 and 1 , and can be expressed in percentage by multiplying the value by 100 .

\section{Root Mean Square Error (RMSE)}

This was computed using:

$$
R M S E=\sqrt{\frac{R S S}{n-p}}
$$

Where, $p=$ the number of parameters in the model, or total number of variables been considered; $n=$ the total number of observations; $R S S=$ the regression sum of squares; $T S S=$ the total sum of squares.

The most suitable models were those with large values of $R^{2}$ and least values of $R M S E$.

\section{Significance of Regression (F-ratio)}

This was used to test the overall significance of the regression equations. The critical value of $\mathrm{F}$ (F-tabulated) at ' $\alpha$ ' equals 0.05 was compared with the variance ratio (F-calculated). Where the F-calculated was greater than the critical values (F-tabulated), such equation was considered significant, and therefore accepted for prediction. 


\section{Model Validation}

Validation involves the testing and comparing of model output with what is observed in the real world. This requires that the predictions of the model be compared with real world data that are independent of the data used in the construction of the models. Models validation requires that some data are set aside, or that new data are obtained for the tests. Model validation was done by dividing the data into two sets. One set for calibrating the models and the other set for validation of the models. The calibrating set was used for model construction while the validating set was used to test the constructed models following Reynolds et al. (1988). The models were validate by: (i) testing for the significant differences in mean predicted and observed values of the dependent variables in all cases, using student t-statistics given as:

$$
t=\frac{\bar{X}_{\text {obs }}-\bar{X}_{\text {pred. }}}{\sqrt{S^{2} \frac{\left(N_{\text {obs. }}+N_{\text {pred. }}\right)}{\left(N_{\text {obs. }}\right)\left(N_{\text {pred. }}\right)}}}
$$

Where, $\bar{X}_{\text {obs }}$. $=$ the mean observed value for a particular response variable in the models; $\bar{X}_{\text {pred }}=$ the mean predicted value for that variable; $N_{\text {obs. }}=$ the total number of the observed values; $N_{\text {pred. }}=$ the total number of the predicted values; $S^{2}$ is the pooled within-group variance (for independent samples with equal variance). The $t$ has $\left(N_{\text {obs. }}-1\right)+\left(N_{\text {pred. }}-1\right)$ degrees of freedom.

(ii) The fitting method consistency was evaluated using the bias and mean square error (MSE) values, with the following expressions:

$$
\begin{array}{r}
\text { Bias }=\frac{\sum_{i=1}^{N} Y_{\text {obs. }}-\hat{Y}_{\text {pred. }}}{N} \\
M S E=\frac{\sum_{i=1}^{N}\left(Y_{\text {obs. }}-\hat{Y}_{\text {pred. }}\right)^{2}}{N}
\end{array}
$$

Where, $Y_{\text {obs. }}=$ observed value; $\hat{Y}_{\text {pred. }}=$ predicted value; $N=$ number of data points.

\section{Results}

\section{Comparisons of the Weibull Parameter Estimation Methods}

Table 1 presents the estimated parameters for the two approaches under moment-based parameter recovery method for the four sites. The first approach, involving the use of arithmetic mean diameter and diameter variance, produced higher values for scale and shape parameters in all the four stands compared to the second approach, which involved the use of quadratic mean diameter and diameter variance. The Weibull parameter estimates under the percentile-based parameter recovery method and the associated approaches for the four sites are presented in Table 2. The estimated mean values for ' $b$ ' and ' $c$ ' for the six approaches are shown in Table 2. Table 3 presents the Weibull parameter estimates under Hybrid method and the associated approaches for the four sites. The parameter estimates under the maximum likelihood method for the four study sites are presented in Table 4. 
Evaluation of Some Weibull Parameter Estimation Methods for Characterizing Stem Diameter 267 Distribution in a Tropical Mixed Forest of Southern Nigeria

Table 5 presents the result of the evaluation statistics for the Weibull parameter recovery methods. The parameter estimation methods and the associated approaches were ranked in the order of appropriateness, with ranks 1 to 14, indicating the best to the worst methods. Generally, percentile-based method was the best for Weibull parameter estimations (Table 5). Within this method, the first approach, which involved the $25^{\text {th }}$ and $95^{\text {th }}$ percentiles, was the best with hybrid method as the least-appropriate.

Table 1

Parameter estimates under moment-based method for the form sites

\begin{tabular}{|c|c|c|c|c|c|c|c|c|c|c|c|c|c|}
\hline \multirow{2}{*}{ Site } & \multirow{2}{*}{ Statistics } & \multicolumn{5}{|c|}{ Approach } & \multirow{2}{*}{ Site } & \multirow{2}{*}{ Statistics } & \multicolumn{5}{|c|}{ Approach } \\
\hline & & $\mathrm{a}$ & $\mathrm{b}_{1}$ & $\mathrm{c}_{1}$ & $\mathrm{~b}_{2}$ & $\mathrm{c}_{2}$ & & & a & $\mathrm{b}_{1}$ & $\mathrm{c}_{1}$ & $\mathrm{~b}_{2}$ & $\mathrm{c}_{2}$ \\
\hline \multirow[t]{2}{*}{ Aking } & Mean & 6.02 & 37.77 & 0.72 & 1.84 & 0.07 & Erokut & Mean & 6.25 & 36.48 & 0.69 & 1.75 & 0.07 \\
\hline & SD & 0.80 & 6.72 & 0.20 & 0.32 & 0.05 & & SD & 1.14 & 6.33 & 0.25 & 0.37 & 0.04 \\
\hline \multirow[t]{2}{*}{ Ekang } & Mean & 6.38 & 33.43 & 0.82 & 1.93 & 0.12 & Ekuri & Mean & 6.82 & 35.95 & 0.74 & 1.88 & 0.07 \\
\hline & SD & 1.15 & 5.59 & 0.26 & 0.35 & 0.13 & & SD & 1.94 & 4.22 & 0.17 & 0.32 & 0.06 \\
\hline
\end{tabular}

N.B.: $a$ - location parameter; $b_{1-2}$ - scale parameter for the first and second approaches; $\mathrm{c}_{1-2}$ - corresponding shape parameter

Table 2

Parameter estimates under percentile-based method for the four sites

\begin{tabular}{|c|c|c|c|c|c|c|c|c|c|c|c|c|c|c|}
\hline \multirow{2}{*}{ Site } & \multirow{2}{*}{ Statistics } & \multicolumn{13}{|c|}{ Approach } \\
\hline & & $\mathrm{a}$ & $b_{1}$ & $\mathrm{c}_{1}$ & $\mathrm{~b}_{2}$ & $\mathrm{c}_{2}$ & $b_{3}$ & $\mathrm{c}_{3}$ & $\mathrm{~b}_{4}$ & $\mathrm{c}_{4}$ & $\mathrm{~b}_{5}$ & $\mathrm{c}_{5}$ & $\mathrm{~b}_{6}$ & $\mathrm{c}_{6}$ \\
\hline \multirow[t]{2}{*}{ Aking } & Mean & 12.04 & 88.31 & 1.56 & 78.92 & 1.53 & 46.59 & 1.22 & 47.29 & 1.15 & 45.59 & 1.26 & 94.88 & 1.08 \\
\hline & SD & 1.61 & 25.34 & 0.25 & 25.24 & 0.26 & 6.80 & 0.35 & 7.79 & 0.37 & 9.47 & 0.47 & 26.49 & 0.23 \\
\hline \multirow[t]{2}{*}{ Ekang } & Mean & 12.49 & 82.54 & 1.52 & 75.40 & 1.48 & 45.83 & 1.17 & 47.18 & 1.09 & 46.62 & 1.21 & 89.63 & 1.06 \\
\hline & SD & 2.29 & 24.66 & 0.27 & 24.02 & 0.28 & 7.70 & 0.37 & 8.79 & 0.38 & 14.98 & 0.51 & 25.82 & 0.26 \\
\hline \multirow[t]{2}{*}{ Erokut } & Mean & 12.75 & 70.40 & 1.63 & 62.65 & 1.60 & 44.27 & 1.24 & 44.92 & 1.23 & 43.79 & 1.36 & 77.19 & 1.13 \\
\hline & SD & 2.31 & 20.62 & 0.25 & 16.49 & 0.26 & 12.81 & 0.34 & 13.86 & 0.34 & 16.65 & 0.40 & 22.13 & 0.28 \\
\hline \multirow[t]{2}{*}{ Ekuri } & Mean & 13.65 & 83.73 & 1.49 & 73.84 & 1.45 & 51.86 & 1.09 & 52.05 & 1.11 & 47.99 & 1.24 & 92.21 & 1.00 \\
\hline & SD & 3.89 & 22.34 & 0.31 & 15.86 & 0.31 & 18.99 & 0.48 & 20.48 & 0.51 & 14.80 & 0.51 & 23.25 & 0.31 \\
\hline
\end{tabular}

N.B.: $a$ - location parameter; $b_{1-6}$ - scale parameters for first to sixth approaches; $c_{1-6}$ - corresponding shape parameters

Table 3

Parameter estimates under hybrid methods for the four sites

\begin{tabular}{|c|c|c|c|c|c|c|c|c|c|c|c|c|}
\hline \multirow{2}{*}{ Site } & \multirow{2}{*}{ Statistics } & \multicolumn{11}{|c|}{ Approach } \\
\hline & & $\mathrm{a}$ & $\mathrm{b}_{1}$ & $\mathrm{c}_{1}$ & $\mathrm{~b}_{2}$ & $\mathrm{c}_{2}$ & $b_{3}$ & $\mathrm{c}_{3}$ & $\mathrm{~b}_{4}$ & $\mathrm{c}_{4}$ & $\mathrm{~b}_{5}$ & $\mathrm{c}_{5}$ \\
\hline \multirow[t]{2}{*}{ Aking } & Mean & 6.02 & 14.90 & 0.03 & 17.26 & 0.03 & 29.72 & 0.03 & 7.78 & 0.03 & 9.45 & 1.29 \\
\hline & SD & 0.80 & 3.74 & 0.01 & 4.47 & 0.01 & 6.37 & 0.01 & 0.39 & 0.01 & 1.33 & 0.36 \\
\hline \multirow[t]{2}{*}{ Ekang } & Mean & 6.40 & 13.05 & 0.03 & 16.47 & 0.03 & 31.71 & 0.03 & 8.06 & 0.03 & 11.20 & 0.91 \\
\hline & SD & 1.14 & 3.29 & 0.01 & 3.22 & 0.01 & 6.00 & 0.01 & 0.41 & 0.01 & 1.33 & 0.37 \\
\hline \multirow[t]{2}{*}{ Erokut } & Mean & 6.38 & 14.23 & 0.04 & 15.42 & 0.04 & 26.50 & 0.04 & 7.48 & 0.04 & 8.47 & 1.39 \\
\hline & SD & 1.15 & 2.10 & 0.01 & 2.18 & 0.01 & 9.65 & 0.01 & 0.45 & 0.01 & 1.22 & 0.36 \\
\hline \multirow[t]{2}{*}{ Ekuri } & Mean & 6.82 & 14.32 & 0.04 & 15.44 & 0.04 & 27.08 & 0.04 & 7.61 & 0.04 & 9.26 & 1.22 \\
\hline & SD & 1.94 & 2.85 & 0.02 & 2.96 & 0.05 & 5.44 & 0.03 & 0.32 & 0.02 & 1.20 & 0.42 \\
\hline
\end{tabular}

N.B.: $a$ - location parameter; $b_{1-5}$ - scale parameters for first to fifth approaches; $c_{1-5}$ - corresponding shape parameters 

Distribution in a Tropical Mixed Forest of Southern Nigeria

Table 4

Parameter estimates under maximum likelihood method for the four sites

\begin{tabular}{llllllllll}
\hline Site & Statistics & $\mathrm{a}$ & $\mathrm{b}$ & $\mathrm{c}$ & Site & Statistics & $\mathrm{a}$ & $\mathrm{b}$ & $\mathrm{c}$ \\
\hline Aking & Mean & 12.04 & 26.60 & 1.08 & Erokut & Mean & 12.49 & 24.24 & 1.01 \\
& SD & 1.61 & 7.00 & 0.24 & & SD & 2.29 & 6.99 & 0.26 \\
\multirow{2}{*}{ Ekang } & Mean & 12.75 & 21.25 & 1.03 & Ekuri & Mean & 13.65 & 22.65 & 1.02 \\
& SD & 2.31 & 5.68 & 0.28 & & SD & 3.89 & 6.17 & 0.27 \\
\hline
\end{tabular}

N.B.: a - location parameter; $\mathrm{b}$ - scale parameter; $\mathrm{c}$ - shape parameter

Table 5

Negative Log-likelihood ( $\mathrm{mLogL}$ ) Statistics for parameter recovery methods

\begin{tabular}{lllll}
\hline Method & Approach & mLogL Statistic & SD & Rank \\
\hline Moment-based & 1 & 273.4319 & 13.52 & 7 \\
\hline Percentile-based & 2 & 1099.7953 & 71.26 & 14 \\
\hline & 1 & 53.7073 & 6.09 & 2 \\
& 3 & 64.1231 & 11.70 & 5 \\
\hline Hybrid & 4 & 158.7628 & 29.01 & 6 \\
\hline & 5 & 164.6199 & 45.61 & 4 \\
& 6 & 153.5218 & 22.19 & 3 \\
\hline ML & 1 & 105.2210 & 16.72 & 11 \\
\hline
\end{tabular}

Weibull fits for diameter distributions in the four study sites and the pooled data are shown in Fig. 2. The result for the Aking, Ekang and Ekuri sites revealed that most of the trees were within the Dbh of 20 and $40 \mathrm{~cm}$, while there were fewer trees in the Dbh range of less than $20 \mathrm{~cm}$ as well as those that were greater than $40 \mathrm{~cm}$, respectively. The result for the Erokut stand however showed a different trend, as most of the trees were within the Dbh of less than $50 \mathrm{~cm}$. Beyond the $50 \mathrm{~cm}$ Dbh, there were marked dropped in the tree frequencies in the site.

\section{Weibull Parameter Predictions from Stand Attributes}

Tables 6 and 7 present the results of the Weibull parameters' predictions under the moment and percentile, and hybrid and maximum likelihood methods respectively. Among the measured tree growth variables tried, the only suitable variable for Weibull parameters' predictions was the quadratic mean diameter $\left(\mathrm{D}_{\mathrm{q}}\right)$.

The results of validation for the selected models under the four methods and their associated approaches are presented in Tables 8 and 9. For all the methods and approaches, the validation tests were not significant $(\mathrm{P}>0.05)$ for scale and shape parameters. This implied that the mean observed and predicted scale and shape parameter values were not significantly different from each other for the four methods and the corresponding approaches adopted. The bias and mean square error (MSE) values for the selected models under the 


\section{Distribution in a Tropical Mixed Forest of Southern Nigeria}

moment-based and the percentile-based methods are presented in Table 10 while Table 11 showed the bias and MSE values for models under the hybrid and maximum likelihood methods. The mean bias and the MSE values were very small and insignificant for virtually all the selected models for the scale and shape parameter under the four methods.
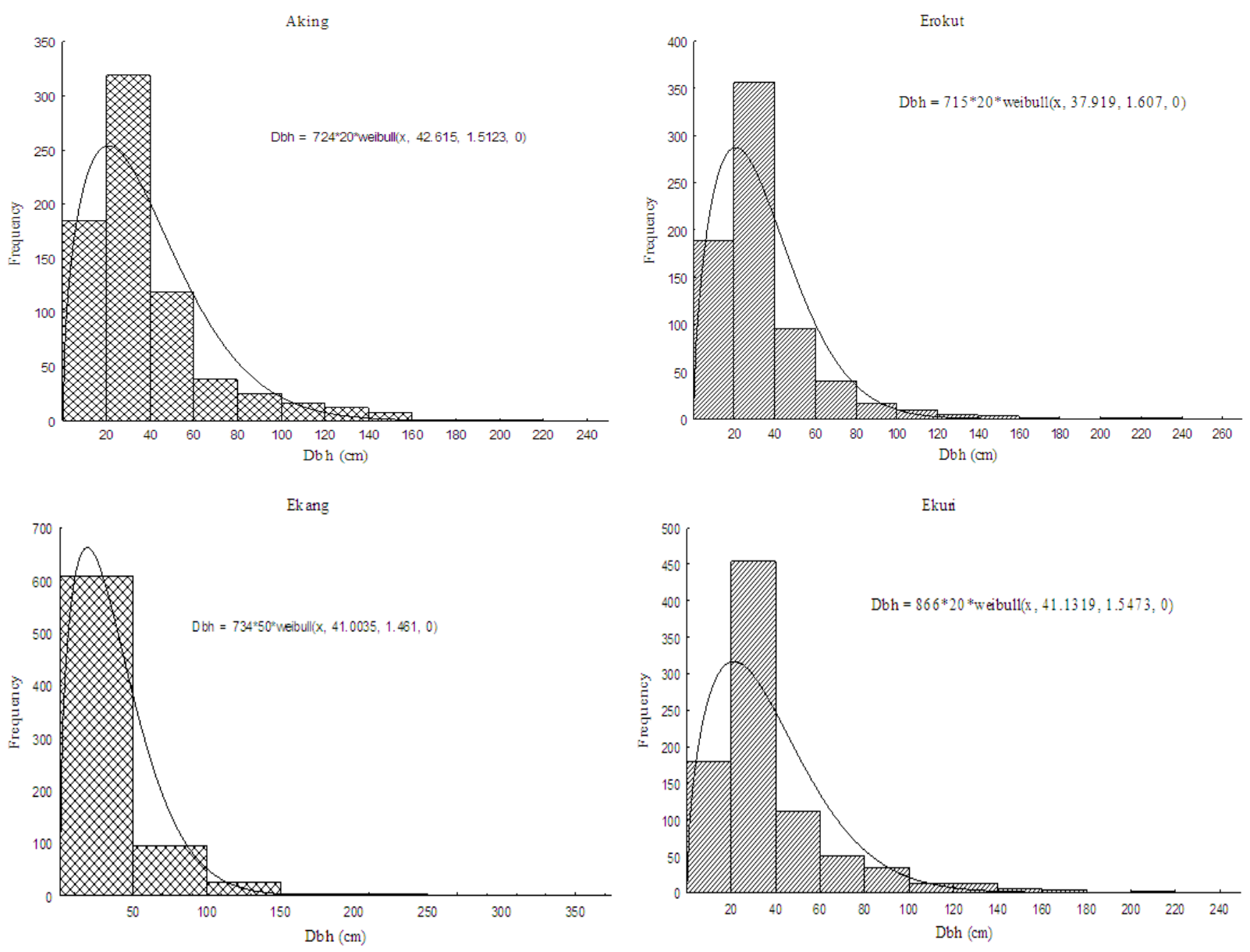

Pooled Data

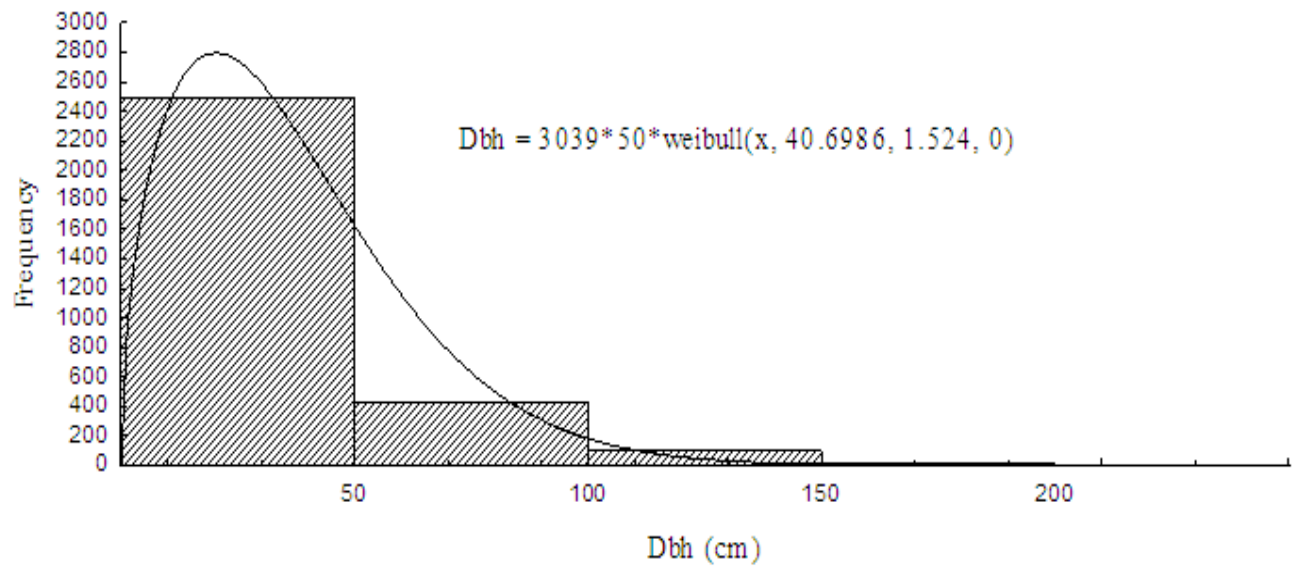

Figure 2. Weibull fits for tree Dbh under the four sites and the pooled data in Oban Forest. 

Distribution in a Tropical Mixed Forest of Southern Nigeria

Table 6

Weibull parameters' prediction models under moment and percentile methods

\begin{tabular}{|c|c|c|c|c|c|c|}
\hline Method & Approach & Model & $\mathrm{R}^{2}$ & RMSE & $\mathrm{F}$ & $\mathrm{P}$ \\
\hline \multirow[t]{6}{*}{ Moment-based } & \multirow[t]{3}{*}{1} & $\mathrm{~b}=9.2045+0.6053 \mathrm{D}_{\mathrm{q}}$ & 0.8703 & 2.1368 & $523.520 *$ & 0.000 \\
\hline & & $\mathrm{c}=1.6659-0.0210 \mathrm{D}_{\mathrm{q}}$ & 0.7173 & 0.1203 & $198.330^{*}$ & 0.000 \\
\hline & & $(\mathrm{a}+\mathrm{b})=21.6069+0.6127 \mathrm{D}_{\mathrm{q}}$ & 0.6823 & 3.8267 & $167.530^{*}$ & 0.000 \\
\hline & \multirow[t]{3}{*}{2} & $\mathrm{~b}=3.0011-0.0261 \mathrm{D}_{\mathrm{q}}$ & 0.4826 & 0.2475 & $72.743 *$ & 0.000 \\
\hline & & $\mathrm{c}=0.4104 \quad-0.075 \mathrm{D}_{\mathrm{q}}$ & 0.5002 & 0.0682 & $78.070 *$ & 0.000 \\
\hline & & $(\mathrm{a}+\mathrm{b})=9.20-0.0223 \mathrm{D}_{\mathrm{q}}$ & 0.0200 & 1.420 & $1.620^{\mathrm{ns}}$ & 0.207 \\
\hline \multirow[t]{13}{*}{ Percentile-based } & \multirow[t]{3}{*}{1} & $\mathrm{~b}=-14.8417+2.1777 \mathrm{D}_{\mathrm{q}}$ & 0.6915 & 0.3160 & $174.81 *$ & 0.000 \\
\hline & & $\ln (b+c)=3.2138+0.0264 D_{q}$ & 0.7240 & 0.1490 & $204.64 *$ & 0.000 \\
\hline & & $\ln (\mathrm{a}+\mathrm{b})=3.3282+0.0251 \mathrm{D}_{\mathrm{q}}$ & 0.7151 & 0.1452 & $195.74 *$ & 0.000 \\
\hline & \multirow[t]{2}{*}{2} & $\ln \mathrm{b}=3.0627+0.0268 \mathrm{D}_{\mathrm{q}}$ & 0.7056 & 0.1585 & $186.92 *$ & 0.000 \\
\hline & & $\ln (b+c)=3.1206+0.0260 D_{q}$ & 0.7074 & 0.1531 & $188.58 *$ & 0.000 \\
\hline & \multirow[t]{2}{*}{3} & $\mathrm{~b}=23.8147+0.5286 \mathrm{D}_{\mathrm{q}}$ & 0.1446 & 11.768 & $13.19^{*}$ & 0.0005 \\
\hline & & $\mathrm{c}=1.8733-0.0157 \mathrm{D}_{\mathrm{q}}$ & 0.1374 & 0.3607 & $12.43^{*}$ & 0.0007 \\
\hline & \multirow[t]{2}{*}{4} & $\mathrm{~b}=26.1782+0.4914 \mathrm{D}_{\mathrm{q}}$ & 0.1068 & 13.0090 & $9.326^{*}$ & 0.0031 \\
\hline & & $\mathrm{c}=1.8556-0.0160 \mathrm{D}_{\mathrm{q}}$ & 0.1346 & 0.3724 & $12.13^{*}$ & 0.0008 \\
\hline & \multirow[t]{2}{*}{5} & $\mathrm{~b}=19.0073+0.6118 \mathrm{D}_{\mathrm{q}}$ & 0.1570 & 12.977 & $14.52^{*}$ & 0.0003 \\
\hline & & $\mathrm{c}=2.2578-0.0225 \mathrm{D}_{\mathrm{q}}$ & 0.1897 & 0.4250 & $18.26^{*}$ & 0.0001 \\
\hline & \multirow[t]{2}{*}{6} & $\ln (b+c)=3.3456+0.0252 D_{q}$ & 0.6921 & 0.1538 & $175.36^{*}$ & 0.000 \\
\hline & & $\mathrm{c}=3.3132+0.0256 \mathrm{D}_{\mathrm{q}}$ & 0.6869 & 0.1584 & $171.11^{*}$ & 0.000 \\
\hline
\end{tabular}

N.B: overall significance of the regression models were tested at $\alpha=0.05$; ${ }^{*}$ significant; ${ }^{\text {ns }}$ not significant

Table 7

Weibull parameters' prediction models under hybrid and ML methods

\begin{tabular}{|c|c|c|c|c|c|c|}
\hline Method & Approach & Model & $\mathrm{R}^{2}$ & RMSE & $\mathrm{F}$ & $\mathrm{P}$ \\
\hline \multirow[t]{15}{*}{ Hybrid } & \multirow[t]{3}{*}{1} & $\mathrm{~b}=13.0+0.0301 \mathrm{D}_{\mathrm{q}}$ & 0.008 & 3.026 & $0.65^{\mathrm{ns}}$ & 0.424 \\
\hline & & $\mathrm{a}+\mathrm{b}=19.2+0.0338 \mathrm{D}_{\mathrm{q}}$ & 0.009 & 3.161 & $0.75^{\mathrm{ns}}$ & 0.390 \\
\hline & & $\mathrm{b}+\mathrm{c}=13.1+0.0295 \mathrm{D}_{\mathrm{q}}$ & 0.008 & 3.024 & $0.62^{\mathrm{ns}}$ & 0.433 \\
\hline & \multirow[t]{3}{*}{2} & $\mathrm{~b}=12.7+0.0752 \mathrm{D}_{\mathrm{q}}$ & 0.042 & 3.282 & $3.43^{\mathrm{ns}}$ & 0.068 \\
\hline & & $\mathrm{a}+\mathrm{b}=22.7+0.0648 \mathrm{D}_{\mathrm{q}}$ & 0.027 & 3.576 & $2.15^{\mathrm{ns}}$ & 0.147 \\
\hline & & $\mathrm{b}+\mathrm{c}=12.8+0.0745 \mathrm{D}_{\mathrm{q}}$ & 0.041 & 3.280 & $3.37^{\mathrm{ns}}$ & 0.070 \\
\hline & \multirow[t]{3}{*}{3} & $\mathrm{~b}=11.2+0.376 \mathrm{D}_{\mathrm{q}}$ & 0.237 & 6.180 & $24.25^{*}$ & 0.000 \\
\hline & & $\ln (\mathrm{a}+\mathrm{b})=3.15+0.0102 \mathrm{D}_{\mathrm{q}}$ & 0.291 & 0.1463 & $32.01 *$ & 0.000 \\
\hline & & $\ln (b+c)=2.69+0.0138 D_{q}$ & 0.290 & 0.1977 & $31.91 *$ & 0.000 \\
\hline & \multirow[t]{3}{*}{4} & $\ln \mathrm{b}=2.97+0.0294 \mathrm{D}_{\mathrm{q}}$ & 0.729 & 0.1642 & $210.17 *$ & 0.000 \\
\hline & & $\ln (\mathrm{a}+\mathrm{b})=3.16+0.0271 \mathrm{D}_{\mathrm{q}}$ & 0.723 & 0.1536 & $203.85^{*}$ & 0.000 \\
\hline & & $\ln (b+c)=2.97+0.0294 D_{q}$ & 0.729 & 0.1642 & $210.15^{*}$ & 0.000 \\
\hline & \multirow[t]{3}{*}{5} & $\ln b=1.61+0.0133 \mathrm{D}_{\mathrm{q}}$ & 0.715 & 0.0767 & $195.70^{*}$ & 0.000 \\
\hline & & $\ln (\mathrm{a}+\mathrm{b})=2.64+0.0060 \mathrm{D}_{\mathrm{q}}$ & 0.068 & 0.2027 & $5.73 *$ & 0.019 \\
\hline & & $\ln \mathrm{b}+\mathrm{c}=1.90+0.0098 \mathrm{D}_{\mathrm{q}}$ & 0.752 & 0.0517 & $236.57^{*}$ & 0.000 \\
\hline \multirow[t]{3}{*}{ ML } & \multirow[t]{3}{*}{1} & $\ln \mathrm{b}=2.2019+0.0210 \mathrm{D}_{\mathrm{q}}$ & 0.482 & 0.1991 & $72.55^{*}$ & 0.000 \\
\hline & & $\ln (\mathrm{b}+\mathrm{c})=2.3063+0.0196 \mathrm{D}_{\mathrm{q}}$ & 0.447 & 0.1999 & $63.04 *$ & 0.000 \\
\hline & & $\ln (\mathrm{a}+\mathrm{b})=2.9703+0.0139 \mathrm{D}_{\mathrm{q}}$ & 0.595 & 0.1056 & $112.46^{*}$ & 0.000 \\
\hline
\end{tabular}

N.B: overall significance of the regression models were tested at $\alpha=0.05$; *significant; ${ }^{\text {ns }}$ not significant 
Evaluation of Some Weibull Parameter Estimation Methods for Characterizing Stem Diameter

Distribution in a Tropical Mixed Forest of Southern Nigeria

Table 8

Model validations under moment- and percentile-based methods

\begin{tabular}{|c|c|c|c|c|c|c|}
\hline Method & Approach & Model & Mean obs. & Mean pred. & $\mathrm{t}_{\mathrm{cal}}$ & $\mathrm{P}$ \\
\hline \multirow[t]{6}{*}{ Moment } & \multirow[t]{3}{*}{1} & $\mathrm{~b}=9.2045+0.6053 \mathrm{D}_{\mathrm{q}}$ & 35.910 & 35.907 & $0.00^{\mathrm{ns}}$ & 1.00 \\
\hline & & $\mathrm{c}=1.6659-0.0210 \mathrm{D}_{\mathrm{q}}$ & 42.280 & 48.640 & $0.06^{\mathrm{ns}}$ & 0.95 \\
\hline & & $(\mathrm{a}+\mathrm{b})=21.6069+0.6127 \mathrm{D}_{\mathrm{q}}$ & 0.741 & 0.740 & $0.07^{\mathrm{ns}}$ & 0.76 \\
\hline & \multirow[t]{3}{*}{2} & $\mathrm{~b}=3.0011-0.0261 \mathrm{D}_{\mathrm{q}}$ & 1.849 & 1.849 & $0.01^{\mathrm{ns}}$ & 0.99 \\
\hline & & $\mathrm{c}=0.4104 \quad-0.075 \mathrm{D}_{\mathrm{q}}$ & 8.214 & 8.219 & $0.38^{\mathrm{ns}}$ & 0.84 \\
\hline & & $(\mathrm{a}+\mathrm{b})=9.20-0.0223 \mathrm{D}_{\mathrm{q}}$ & 0.082 & -0.899 & $0.02^{\mathrm{ns}}$ & 0.98 \\
\hline \multirow[t]{13}{*}{ Percentile } & \multirow[t]{3}{*}{1} & $\mathrm{~b}=-14.8417+2.1777 \mathrm{D}_{\mathrm{q}}$ & 81.240 & 81.240 & $0.00^{\mathrm{ns}}$ & 1.00 \\
\hline & & $\ln (b+c)=3.2138+0.0264 D_{q}$ & 4.437 & 4.435 & $0.03^{\mathrm{ns}}$ & 0.98 \\
\hline & & $\ln (\mathrm{a}+\mathrm{b})=3.3282+0.0251 \mathrm{D}_{\mathrm{q}}$ & 4.377 & 4.378 & $0.04^{\mathrm{ns}}$ & 0.96 \\
\hline & \multirow[t]{2}{*}{2} & $\ln b=3.0627+0.0268 D_{q}$ & 4.266 & 4.266 & $0.00^{\mathrm{ns}}$ & 1.00 \\
\hline & & $\ln (b+c)=3.1206+0.0260 D_{q}$ & 4.267 & 1.979 & $0.15^{\mathrm{ns}}$ & 0.00 \\
\hline & \multirow[t]{2}{*}{3} & $\mathrm{~b}=23.8147+0.5286 \mathrm{D}_{\mathrm{q}}$ & 47.140 & 47.137 & $0.00^{\mathrm{ns}}$ & 1.00 \\
\hline & & $\mathrm{c}=1.8733-0.0157 \mathrm{D}_{\mathrm{q}}$ & 1.179 & 1.181 & $0.03^{\mathrm{ns}}$ & 0.98 \\
\hline & \multirow[t]{2}{*}{4} & $\mathrm{~b}=26.1782+0.4914 \mathrm{D}_{\mathrm{q}}$ & 47.860 & 47.880 & $0.00^{\mathrm{ns}}$ & 1.00 \\
\hline & & $\mathrm{c}=1.8556-0.0160 \mathrm{D}_{\mathrm{q}}$ & 1.148 & 1.150 & $0.03^{\mathrm{ns}}$ & 0.97 \\
\hline & \multirow[t]{2}{*}{5} & $\mathrm{~b}=19.0073+0.6118 \mathrm{D}_{\mathrm{q}}$ & 46.000 & 46.001 & $0.00^{\mathrm{ns}}$ & 1.00 \\
\hline & & $\mathrm{c}=2.2578-0.0225 \mathrm{D}_{\mathrm{q}}$ & 1.267 & 1.266 & $0.02^{\mathrm{ns}}$ & 0.98 \\
\hline & \multirow[t]{2}{*}{6} & $\ln (b+c)=3.3456+0.0252 D_{q}$ & 1.068 & 4.442 & $0.00^{\mathrm{ns}}$ & 1.00 \\
\hline & & $\mathrm{c}=3.3132+0.0256 \mathrm{D}_{\mathrm{q}}$ & 4.457 & 4.457 & $0.08^{\mathrm{ns}}$ & 0.91 \\
\hline
\end{tabular}

$\alpha=0.05$; ns: not significant; obs.: observed value; pred.: predicted value; t: t-calculated; P: probability value

Table 9

Model validation under hybrid and ML methods

\begin{tabular}{|c|c|c|c|c|c|c|}
\hline Method & Approach & Model & Mean obs. & Mean pred. & $\mathrm{t}_{\mathrm{cal}}$ & $\mathrm{P}$ \\
\hline \multirow[t]{15}{*}{ Hybrid } & \multirow[t]{3}{*}{1} & $\mathrm{~b}=13.0+0.0301 \mathrm{D}_{\mathrm{q}}$ & 14.331 & 14.180 & $0.01^{\mathrm{ns}}$ & 0.99 \\
\hline & & $\mathrm{a}+\mathrm{b}=19.2+0.0338 \mathrm{D}_{\mathrm{q}}$ & 20.696 & 20.691 & $0.01^{\mathrm{ns}}$ & 0.99 \\
\hline & & $\mathrm{b}+\mathrm{c}=13.1+0.0295 \mathrm{D}_{\mathrm{q}}$ & 14.367 & 14.402 & $0.10^{\mathrm{ns}}$ & 0.92 \\
\hline & \multirow[t]{3}{*}{2} & $\mathrm{~b}=12.7+0.0752 \mathrm{D}_{\mathrm{q}}$ & 16.005 & 16.008 & $0.04^{\mathrm{ns}}$ & 0.97 \\
\hline & & $\mathrm{a}+\mathrm{b}=22.7+0.0648 \mathrm{D}_{\mathrm{q}}$ & 25.547 & 25.559 & $0.03^{\mathrm{ns}}$ & 0.98 \\
\hline & & $\mathrm{b}+\mathrm{c}=12.8+0.0745 \mathrm{D}_{\mathrm{q}}$ & 16.039 & 16.087 & $0.13^{\mathrm{ns}}$ & 0.90 \\
\hline & \multirow[t]{3}{*}{3} & $\mathrm{~b}=11.2+0.376 \mathrm{D}_{\mathrm{q}}$ & 27.776 & 27.790 & $0.02^{\mathrm{ns}}$ & 0.99 \\
\hline & & $\ln (\mathrm{a}+\mathrm{b})=3.15+0.0102 \mathrm{D}_{\mathrm{q}}$ & 3.605 & 3.600 & $0.21^{\mathrm{ns}}$ & 0.83 \\
\hline & & $\ln (b+c)=2.69+0.0138 D_{q}$ & 3.298 & 3.398 & $0.02^{\mathrm{ns}}$ & 0.98 \\
\hline & \multirow[t]{3}{*}{4} & $\ln b=2.97+0.0294 D_{q}$ & 4.268 & 4.267 & $0.01^{\mathrm{ns}}$ & 0.99 \\
\hline & & $\ln (\mathrm{a}+\mathrm{b})=3.16+0.0271 \mathrm{D}_{\mathrm{q}}$ & 4.357 & 4.356 & $0.03^{\mathrm{ns}}$ & 0.98 \\
\hline & & $\ln (b+c)=2.97+0.0294 D_{q}$ & 4.288 & 4.267 & $0.02^{\mathrm{ns}}$ & 0.98 \\
\hline & \multirow[t]{3}{*}{5} & $\ln b=1.61+0.0133 \mathrm{D}_{\mathrm{q}}$ & 2.196 & 2.197 & $0.04^{\mathrm{ns}}$ & 0.97 \\
\hline & & $\ln (\mathrm{a}+\mathrm{b})=2.64+0.0060 \mathrm{D}_{\mathrm{q}}$ & 2.903 & 2.904 & $0.06^{\mathrm{ns}}$ & 0.95 \\
\hline & & $\ln \mathrm{b}+\mathrm{c}=1.90+0.0098 \mathrm{D}_{\mathrm{q}}$ & 2.333 & 2.332 & $0.07^{\mathrm{ns}}$ & 0.95 \\
\hline \multirow[t]{3}{*}{ ML } & \multirow[t]{3}{*}{1} & $\ln b=2.2019+0.0210 D_{q}$ & 3.127 & 3.125 & $0.03^{\mathrm{ns}}$ & 0.97 \\
\hline & & $\ln (\mathrm{b}+\mathrm{c})=2.3063+0.0196 \mathrm{D}_{\mathrm{q}}$ & 3.582 & 3.584 & $0.03^{\mathrm{ns}}$ & 0.97 \\
\hline & & $\ln (\mathrm{a}+\mathrm{b})=2.9703+0.0139 \mathrm{D}_{\mathrm{q}}$ & 3.172 & 3.171 & $0.09^{\mathrm{ns}}$ & 0.93 \\
\hline
\end{tabular}

$\alpha=0.05$; ns: not significant; obs.: observed value; pred.: predicted value; $t$ : $t$-calculated; P: probability value 

Distribution in a Tropical Mixed Forest of Southern Nigeria

Table 10

Bias and MSE values for the models under moment and percentile methods

\begin{tabular}{|c|c|c|c|c|}
\hline Method & Approach & Model & Bias & MSE \\
\hline \multirow[t]{6}{*}{ Moment } & \multirow[t]{3}{*}{1} & $\mathrm{~b}=9.2045+0.6053 \mathrm{D}_{\mathrm{q}}$ & 0.0043 & 0.0036 \\
\hline & & $\mathrm{c}=1.6659-0.0210 \mathrm{D}_{\mathrm{q}}$ & -0.1715 & 0.0356 \\
\hline & & $(\mathrm{a}+\mathrm{b})=21.6069+0.6127 \mathrm{D}_{\mathrm{q}}$ & 0.0001 & 0.000012 \\
\hline & \multirow[t]{3}{*}{2} & $\mathrm{~b}=3.0011-0.0261 \mathrm{D}_{\mathrm{q}}$ & 0.0001 & 0.00005 \\
\hline & & $\mathrm{c}=0.4104 \quad-0.075 \mathrm{D}_{\mathrm{q}}$ & 0.0022 & 0.0019 \\
\hline & & $(\mathrm{a}+\mathrm{b})=9.20-0.0223 \mathrm{D}_{\mathrm{q}}$ & 0.0833 & 0.0077 \\
\hline \multirow[t]{13}{*}{ Percentile } & \multirow[t]{3}{*}{1} & $\mathrm{~b}=-14.8417+2.1777 \mathrm{D}_{\mathrm{q}}$ & -0.0218 & 0.1200 \\
\hline & & $\ln (b+c)=3.2138+0.0264 D_{q}$ & -0.0001 & 0.00015 \\
\hline & & $\ln (\mathrm{a}+\mathrm{b})=3.3282+0.0251 \mathrm{D}_{\mathrm{q}}$ & 0.2444 & 0.0637 \\
\hline & \multirow[t]{2}{*}{2} & $\ln \mathrm{b}=3.0627+0.0268 \mathrm{D}_{\mathrm{q}}$ & -0.0001 & 0.000019 \\
\hline & & $\ln (b+c)=3.1206+0.0260 D_{q}$ & 0.0638 & 0.0045 \\
\hline & \multirow[t]{2}{*}{3} & $\mathrm{~b}=23.8147+0.5286 \mathrm{D}_{\mathrm{q}}$ & 0.0193 & 0.1302 \\
\hline & & $\mathrm{c}=1.8733-0.0157 \mathrm{D}_{\mathrm{q}}$ & -0.0002 & 0.00012 \\
\hline & \multirow[t]{2}{*}{4} & $\mathrm{~b}=26.1782+0.4914 \mathrm{D}_{\mathrm{q}}$ & 0.0223 & 0.1678 \\
\hline & & $\mathrm{c}=1.8556-0.0160 \mathrm{D}_{\mathrm{q}}$ & -0.0003 & 0.00012 \\
\hline & \multirow[t]{2}{*}{5} & $\mathrm{~b}=19.0073+0.6118 \mathrm{D}_{\mathrm{q}}$ & 0.0282 & 0.1696 \\
\hline & & $\mathrm{c}=2.2578-0.0225 \mathrm{D}_{\mathrm{q}}$ & -0.0003 & 0.0002 \\
\hline & \multirow[t]{2}{*}{6} & $\ln (b+c)=3.3456+0.0252 D_{q}$ & 0.2489 & 0.0661 \\
\hline & & $\mathrm{c}=3.3132+0.0256 \mathrm{D}_{\mathrm{q}}$ & -0.0940 & 0.0095 \\
\hline
\end{tabular}

Table 11

Bias and MSE values for the models under the hybrid and ML methods

\begin{tabular}{lllll}
\hline Method & Approach & Model & Bias & MSE \\
\hline Hybrid & 1 & $\mathrm{~b}=13.0+0.0301 \mathrm{D}_{\mathrm{q}}$ & 0.0025 & 0.0072 \\
& & $\mathrm{a}+\mathrm{b}=19.2+0.0338 \mathrm{D}_{\mathrm{q}}$ & 0.0046 & 0.0076 \\
& $\mathrm{~b}+\mathrm{c}=13.1+0.0295 \mathrm{D}_{\mathrm{q}}$ & 0.0014 & 0.0072 \\
& 2 & $\mathrm{~b}=12.7+0.0752 \mathrm{D}_{\mathrm{q}}$ & 0.0025 & 0.0090 \\
& $\mathrm{a}+\mathrm{b}=22.7+0.0648 \mathrm{D}_{\mathrm{q}}$ & 0.0046 & 0.0110 \\
& $\mathrm{~b}+\mathrm{c}=12.8+0.0745 \mathrm{D}_{\mathrm{q}}$ & 0.0016 & 0.0090 \\
& $\mathrm{~b}=11.2+0.376 \mathrm{D}_{\mathrm{q}}$ & 0.0069 & 0.0333 \\
& 3 & $\ln (\mathrm{a}+\mathrm{b})=3.15+0.0102 \mathrm{D}_{\mathrm{q}}$ & 0.0003 & 0.000018 \\
& & $\ln (\mathrm{b}+\mathrm{c})=2.69+0.0138 \mathrm{D}_{\mathrm{q}}$ & 0.0002 & 0.000033 \\
& & $\ln \mathrm{b}=2.97+0.0294 \mathrm{D}_{\mathrm{q}}$ & -0.0002 & 0.000018 \\
& 4 & $\ln (\mathrm{a}+\mathrm{b})=3.16+0.0271 \mathrm{D}_{\mathrm{q}}$ & -0.0001 & 0.000017 \\
& & $\ln (\mathrm{b}+\mathrm{c})=2.97+0.0294 \mathrm{D}_{\mathrm{q}}$ & -0.0002 & 0.000019 \\
& & $\ln \mathrm{b}=1.61+0.0133 \mathrm{D}_{\mathrm{q}}$ & -0.0001 & 0.000004 \\
& 5 & $\ln (\mathrm{a}+\mathrm{b})=2.64+0.0060 \mathrm{D}_{\mathrm{q}}$ & -0.0001 & 0.000038 \\
& & $\ln \mathrm{b}+\mathrm{c}=1.90+0.0098 \mathrm{D}_{\mathrm{q}}$ & -0.00004 & 0.000002 \\
& & $\ln \mathrm{b}=2.2019+0.0210 \mathrm{D}_{\mathrm{q}}$ & 0.0001 & 0.000033 \\
& & $\ln (\mathrm{b}+\mathrm{c})=2.3063+0.0196 \mathrm{D}_{\mathrm{q}}$ & 0.00001 & 0.000008
\end{tabular}

\section{Discussion}

After several modelling trials, percentile-based method was found to be the most suitable compared to the moment-based, hybrid and the maximum likelihood methods, going by the results of the evaluation statistics 
Evaluation of Some Weibull Parameter Estimation Methods for Characterizing Stem Diameter 273 Distribution in a Tropical Mixed Forest of Southern Nigeria

with $25^{\text {th }}$ and $95^{\text {th }}$ percentile pair as the most appropriate for Weibull parameters recovery and predictions. This is in line with the finding of Gorgoso-Varela et al. (2007), who noted that percentile approach was the most accurate in comparisons to the methods of moment and maximum likelihood. This is, however, contrary to the work of Zerda (2012), who reported that percentile method provided poor approximation of true distribution parameters after considering only $25^{\text {th }}$ and $75^{\text {th }}$ percentiles. The result also disagrees with the report by Akbar $e t$ al. (2014) and George (2014), who tried only $17^{\text {th }}$ and $97^{\text {th }}$ percentiles for shape parameter estimation and $40^{\text {th }}$ and $80^{\text {th }}$ percentile for scale parameter, and concluded that, percentile estimator performed poorer than maximum likelihood and moment-based estimators. The difference in the findings of previous workers compared to the current study may have resulted from the choices of percentiles adopted, and their inability to try and compared other percentile combinations considered in the current work. It could also be that the differences in sample sizes used by the previous workers impacted the results obtained. This corroborates the report by Marks (2005), who noted that sample size affects the successes of Weibull parameter estimation methods. The parameters' estimates may have also been influenced by the species diversity in the Oban Forest.

The result of this study was not also in consonance with Liu et al. (2004) and Oyebade et al. (2013), who tried only maximum likelihood method for predictions in mono-species planted forests and reported a good prediction of Weibull parameters without testing the appropriateness of other methods, especially the percentile-based. The result also disagrees with the works of Al-Fawzan (2000) and Lei (2008), who independently reported that moment-based method was superior for estimating Weibull scale and shape parameters compared to maximum likelihood method for a mono-species stand of Pinus tabulaeformis. Similarly, the result is not in consonance with the report by Sheykholeslami et al. (2011) that moment method is the most appropriate for Weibull parameter estimation in a mixed stand. The difference in findings may have resulted from species and structural diversities as well as age composition of the stands in question. Generally, the hybrid method gave poor, and the least reliable estimates of Weibull parameters. This is in line with the finding of Poudel and Cao (2013), who reported hybrid method to be the worst in terms of Weibull parameter estimations.

Only quadratic mean diameter $\left(\mathrm{D}_{\mathrm{q}}\right)$ was found to be a good predictor of Weibull parameters in Oban Forest. This corroborates the work of Navar (2014), where quadratic mean diameter was found the only suitable predictor variable for Weibull parameter predictions with very high coefficients of determination $\left(\mathrm{R}^{2}\right)$ and small RMSE values. When other variables were included in the models, there were virtually no meaningful contributions. The suitability of quadratic mean diameter was confirmed by Gorgoso-Varela et al. (2007) with very high (0.99) adjusted $\mathrm{R}^{2}$. The result is however in sharp contrast with the report by Ajayi (2013), who noted that age is the most-relevant variable for predicting Weibull parameter. This is probably due to the scope of his study, which focused on a monoculture stands using maximum likelihood estimator. The percentile-based method and associated approaches gave good predictions. Better prediction equations were obtained using a combination of $25^{\text {th }}$ and $95^{\text {th }}$ percentiles as well as a combination of $24^{\text {th }}$ and $93^{\text {rd }}$ percentiles compared to other percentile pairs.

\section{Conclusion}

The study showed that percentile-based method was the best for Weibull parameter recovery and prediction in Oban Forest. Among all the approaches adopted under this method, the approach involving the $25^{\text {th }}$ and $95^{\text {th }}$ percentiles was the most appropriate. Although moment and maximum likelihood methods had some predictive ability for Weibull parameters, the model selection criteria revealed inadequacies for 
subsequent adoptions in the study area. The results of this study indicated that a successful parameter recovery or prediction methods or models, as the case may be, for a given forest, or situation, might not be so for others in different areas. Therefore, it is safer to be conscious of the peculiarities of different ecosystems considered as well as the range of data included before generalizations are made about best or worst methods or approaches. It is evident that percentile method and approaches yielded better results, a slight modification in site condition may influence result in other forests. Hence, caution is emphasized before recommendations are made as to which method(s) are appropriate or suitable. For most of the models presented in this study, the validation results showed that the observed and the predicted values were not significantly different from each other. The bias and MSE values were also very small, especially for the $25^{\text {th }}$ and $95^{\text {th }}$ percentile pair, which further justified the suitability of the selected models for prediction studies in Oban Forest.

\section{References}

Adesoye, P.O. (2002) Integrated system of forest stand models for Nauclea diderrichii, De Wild \& Th. Dur in Omo Forest Reserve, Nigeria. Ph.D. Thesis, University of Ibadan, Nigeria. 175pp.

Ajayi, S. (2013) Diameter Distribution for Gmelina Arborea (ROXB) Plantations in Ukpon River Forest Reserve, Cross River State, Nigeria. Afrrev Stech 2(1): 64-82.

Akbar, M., Shaukat, S.S., Ahmed, M., Hussain, A., Hyder, S., Ali, S., Hussain, F., Raza, G., Hussain, S.A., Ali, H., Raza, M., Ali, S. and Ali, K. (2014) Characterization of diameter distribution of some tree species from Gilgit-baltistan using Weibull distribution. Journal of Biodiversity and Environmental Sciences 5(4): 437-444.

Al-fawzan, M.A. (2000) Methods for estimating the parameters of the Weibull distribution. InterStat, statistics on the Internet. Consulted 05 February. 2013: URL: http://www.ip.statjournals.net:2002/InterStat/ARTICLES/2000.html-ssi.

Beets, P.N., Kimberley, M.O., Oliver, G.R., Pearce, S.H., Graham, J.D. and Brandon, A. (2012) Allometric Equations for Estimating Carbon Stocks in Natural Forest in New Zealand. Forests 3: 818-839.

Cao, Q.V. (2007). Incorporating whole-stand and individual-tree models in a stand table projection system. Forest Science 53: 45-49.

Eerikäinen, K. and Maltamo, M. (2003) A percentile based basal area diameter distribution model for predicting the stand development of Pinus kesiya plantations in Zambia and Zimbabwe. Forest Ecology and Management 172: 109-124.

George, F. (2014) A Comparison of Shape and Scale Estimators of the Two-Parameter Weibull Distribution. Journal of Modern Applied Statistical Methods 13(1): 23-35.

Gorgoso-Varela, J.J., Álvarez González, J.G. Rojo, A. and Grandas-Arias, J.A. (2007) Modelling diameter distributions of Betula alba L. stands in northwest Spain with the two-parameter Weibull function. Investigación Agraria: Sistemas Recursos Forestales 16(2): 113-123.

Gorgoso-Varela, J.J., Rojo A., Camara-Obregon, A. and Dieguez-Aranda, U. (2012) A comparison of estimation methods for fitting Weibull, Johnson's $\mathrm{S}_{\mathrm{B}}$ and beta functions to Pinus pinaster, Pinus radiate and Pinus sylvestris stands in northwest Spain. Forest Systems 21(3): 446-459.

Husch, B., Beer, T.W. and Kershaw, J.A. (2003) Forest Mensuration. Fourth Edition. John Wiley and Sons, Inc., Hoboken, New Jersey. 443pp.

Lei, Y. (2008) Evaluation of three methods for estimating the Weibull distribution parameters of Chinese pine (Pinus tabulaeformis). Journal of Forest Science 54(12): 566-571.

Liu C., Zhang S.Y., Lei Y., Newton P.F. and Zhang L. (2004) Evaluation of three methods for predicting diameter distributions of black spruce (Picea mariana) plantations in central Canada. Canadian Journal of Forest Research 34: 2424-2432.

Marks, N.B. (2005) Estimation of Weibull parameters from common percentiles. Journal of Applied Statistics 32(1): 17-24.

McLaughlin, M.P. (2014) Compendium of Common Probability Distributions. Second Edition. www.causascientia.org. 136pp.

Nigerian Forestry Information System, NFIS. (2011) Cross River States Forestry Information. Forest Reserves. www.frin.gov.ng/forestryinformation/2011.html. 6pp. Retrieved March, 2014.

Oates, J., Sunderland-Groves, J., Bergl, R., Dunn, A., Nicholas, A., Takang, E., Omeni, F., Imong, I., Fotso, R., Nkembi, L. and Williamson, L. (2007) Regional Action Plan for the Conservation of the Cross River Gorilla (Gorilla gorilla diehli). IUCN/SSC Primate Specialist Group and Conservation International, Arlington, VA, USA. 30pp. http://www.primate-sg.org/action.plans.htm. 
Evaluation of Some Weibull Parameter Estimation Methods for Characterizing Stem Diameter 275 Distribution in a Tropical Mixed Forest of Southern Nigeria

Ojonigu F. A., Tabitha S., Innocent A. and Seidu O.M. (2010) Assessing changes in Kangaro Forest, Kaduna State, Nigeria, Using Remote Sensing and GIS. Research Journal of Applied Sciences, Engineering and Technology 2(2): 121-132.

Osman, H.M., Idris, Z.A. and Ibrahim, M.M. (2013) Height-Diameter Prediction Models for Some Utilitarian Natural Tree Species. Journal of Forest Products and Industries 2(2): 31-39.

Oyebade, B.A, Popo-ola, F.S. and Alex, A. (2012) Height-Diameter Equations for Eight Midwestern Rainforest Species in Nigeria, Using Monserud's Model. ARPN Journal of Science and Technology 2(5): 479-486.

Oyebade B.A., Ogu, C.I. and Ekeke, B.A. (2013) Weibull diameter distribution and maximum likelihood Estimators (MLE) in Pinus caribaea plantation, Enugu, Ngwo, Nigeria. ARPN Journal of Agricultural and Biological Science 8(8): 575-579.

Özçelik, R., Yavuz, H., Karatepe, Y., Gürlevik, N. and Kiriş, R. (2014) Development of ecoregion-based height-diameter models for 3 economically important tree species of southern Turkey. Turkish Journal of Agriculture and Forestry 38: 399-412.

Podlaski, R. (2008) Characterization of diameter distribution data in near-natural forest using the Birnbaum-Saunders distribution. Canadian Journal of Forest Resources 38: 518- 527.

Poudel, K.P. and Cao, Q.V. (2013) Evaluation of Methods to Predict Weibull Parameters for Characterizing Diameter Distributions. Forest Science 59(2): 243-252.

Sharma, M. and Parton, J. (2007) Height-diameter equations for boreal tree species in Ontario using a mixed-effects modeling approach. Forest Ecology and Management 249(3): 187-198.

Sheykholeslami, A., Kia, P.K. and Kia, L.A. (2011) A Study of Tree Distribution in Diameter Classes in Natural Forests of Iran (Case Study: Liresara Forest). Annals of Biological Research 2(5): 283-290.

Zerda, I. (2012) An experimental comparison of popular estimation methods for the weibull, gamma and gompertz distributions. Schedae Informaticae 20: 67-82. 